\title{
Experimental Optimization of Using Natural Pozzolan in Chloride lon Exposed Concrete via Taguchi Method
}

\author{
Amir Behshad*, Mostafa Askarian Zardak, Yaser Mohammadi
}

\begin{abstract}
Concrete durability is one of the most important concerns in the field of construction. The environmentally friendly materials that can provide the durability are of great value in the construction of concrete structures. The use of natural pozzolans is one of the cheapest and most efficient methods in this field, which offers a good performance from environmental and economic point of view and satisfies required engineering parameters. In this study, the effect of using natural pozzolan in the manufacture of concrete exposed to sulfate and chloride ion of Oman sea water was investigated. The Taguchi optimization method was used to reduce the number of samples prepared, reduce the cost of experiments and achieve an optimal mix design. The four parameters, namely water to cement ratio, different percentages of natural pozzolan, super-plasticizer and cement grade with different ratios, were considered as problem variables. The Taguchi optimization method proposed 8 mix designs based on the defined levels for the variables. By constructing 96 samples, two parameters of permeability and water absorption from Oman Sea and drinking water were investigated in the samples. By introducing the results of the experiments into the Taguchi method, the final optimal design was presented by this method, and by constructing 12 additional samples and conducting permeability and water absorption experiments, the behavior of this optimal mix design was verified. The appropriate performance of the Taguchi method was demonstrated by obtaining the optimal mix designs from the Taguchi method, constructing this mix design and comparing the results with the regulation limitations. The results showed that it is acceptable to use natural pozzolan under moderate to severe chloride and sulfate ion attacks, but it is not recommended in the extreme environmental conditions.
\end{abstract}

Keywords: Permeability; Pozzolan; Taguchi Method; Water Absorption

\section{INTRODUCTION}

Today, the use of natural pozzolans is of great importance due to the improvement of the concrete structure and the increase of concrete performance in aggressive environments considering the economic efficiency and environmental impacts. Replacing the cement with these types of pozzolans (depending on the replacement percentage) has shown significant effects on the compressive strength, initial setting time and durability of concrete. The use of pozzolanic cement containing $55 \%$ of a natural pozzolanic material from Turkey demonstrated the ability of this compound to reduce the spread of the alkali-silica reaction [1]. Due to the inconsistency of the structural properties, no certain percentage of natural pozzolans can be determined to improve the concrete properties, and the necessary experiments should be performed for each type of pozzolan. In the study of Najimi et al. (2011) on zeolite as a natural pozzolan, it was found that replacing the cement with $30 \%$ of the natural pozzolans in the mix designs can have beneficial effects on water and chloride penetration and corrosion rate [2]. Ezzian et al. (2005) performed some experiments and managed to find an optimal percentage of natural pozzolan between 15 and $20 \%$ for cement replacement in the samples at temperatures of 20,40 and 60 ${ }^{\circ} \mathrm{C}$ [3]. In another study by Nguyen et al. to investigate the size of natural pozzolans for reducing the ettringite production rate, they found that the smaller the particle size, the better the effect on the amount of produced ettringite [4]. In addition to the environmental issues and not requiring much $\mathrm{CO}_{2}$ production and release process unlike cement, the use of natural pozzolan is economically optimal and results in the reduced heat generation and concrete permeability [5]. In fact, pozzolanic materials are the most important factor in reducing the concrete permeability, which is achieved by reducing the volume of large cavities in concrete [6]. To this end, a study conducted in Algeria by Kaid et al. concluded that the use of Algerian natural pozzolans as a percentage of cement replacement can improve the parameters related to durability, corrosion and resistance to acidic environment [7]. In the present study, the natural pozzolan of Taftan Mountain and the water of the Oman Sea were used. The permeability and water absorption tests were performed using BS EN 12390-8 permeability test standards [8] and BS 1881-part 122 half-hour water absorption test [9].

Merida and Kharchi [10] investigate the concrete properties has been manufactured by blended cement including volcanic origin Algerian natural pozzolan and Portland cement. They included that using such pozzolan improves the pulse velocity and sulphate resistance of concrete.

Omrane et al. [11] investigate the performance and durability of self-compacting concrete (SCC) contain natural pozzolan and recycled concrete aggregates. The results of their research work shows that using pozzolan develop a significant compressive strength to mixtures without it at 120 days. The incorporation of $15 \%$ and $20 \%$ pozzolan in SCC decreased the penetration depth of chloride ions to $50 \%$ and also decreased the mass loss under sulfuric acid attack. A comprehend review regarding the mechanical and durability characteristics as well as the microstructural properties of natural pozzolan based geopolymers and their potential as binding material are reported in Firdous et al. [12] research work. Najimi and Ghafoori [13] find the most proper optimum using hybrid aluminosilicate precursors in alkali-activated concretes made with having different proportions of natural pozzolan (low calcium precursor) and also blast furnace slag (high calcium precursor). Their experimental investigation shows that the optimum sodium hydroxide concentration was dependent on the precursor and 
activator combinations as well as the expected fresh, strength, dimensional stability and transport properties.

In this study, by replacing the cement with Taftan natural pozzolans and using the Taguchi method, the optimum percentage of the pozzolan for the minimum permeability and water absorption was obtained in the both Oman Sea water and drinking water. By comparing the optimum and laboratory values with the standards of the "National Concrete Durability Regulation in Oman Sea", the possibility of using this pozzolan in the construction industry was investigated for the coastal cities of the Oman Sea.

\section{TAGUCHI METHOD AND TEST MODEL}

The Taguchi optimization technique was introduced in the 1950 s by the Japanese scientist Taguchi [14]. This method is used to save the number of sample preparation, reduce the cost of experiments and also obtain an optimal design (in this study, pozzolanic concrete mix design). This method is optimized by setting the controllable parameters and reducing the sensitivity of the system performance relative to the uncontrollable parameters of optimal system performance [15-17]. Other advantages of this method include the simultaneous optimization of several factors and evaluation of the impact of controllable factors [16]. The parameters in an experiment are divided into two groups of controllable and uncontrollable parameters.

In the Taguchi method, considering the minimum effects of uncontrollable parameters, it is tried to optimize the system by setting the controllable parameters.

One of the most important parameters in this method is the "signal to noise $(\mathrm{S} / \mathrm{N})$ ratio". In terms of quality, Taguchi divided the qualitative characteristics into three categories based on this parameter [18].

1. Larger the better: This parameter is used when the problem objective is to reach the maximum value which is given by Eq. (1).

$\frac{S}{N}=-10 \log _{10}\left(\frac{1}{n} \sum_{i=1}^{n} \frac{1}{y_{i}^{2}}\right)$

2. Nominal the best: This parameter is used when the problem objective is to produce results around a given value, which is expressed by Eq. (2).

$\frac{S}{N}=-10 \log _{10}\left(\frac{1}{n} \sum_{i=1}^{n}\left(y_{i}-y_{o}\right)^{2}\right)$

3. Smaller the better: This parameter is used when the problem objective is to reach the minimum value which is given by Eq. (3).

$\frac{S}{N}=-10 \log _{10}^{\left(\frac{1}{n} \sum_{i=1}^{n} y_{i}^{2}\right)}$
In Eqs. (1)-(3), $y_{i}$ is the value of the obtained results and $n$ is the number of replications per experiment.

Any level of a factor with the highest $S / N$ ratio is known as the optimal level. In addition, any factor where the difference between its levels (delta) has the highest value is the most effective factor in the test process and, consequently, the most influential factor in the optimization process [19].

The parameters of this study are as follows:

- Taftan natural pozzolan (pozzolan)

- Water to cement ratio (cement with pozzolan) - (w/b)

- Grade of used cement - (c)

- Super-plasticizer - (sp).

The levels (the number of ratios provided for each parameter to prepare the test mix design) and the quantity of each variable parameter related to these parameters are listed in Table (1). For example, for the water to cement ratio, two ratios of 0.4 and 0.45 , namely two levels, are considered and for the pozzolan to cement ratio, four ratios of $0, .10, .20$ and $.25 \%$, namely four levels, are defined.

Table 1 Parameters and related levels

\begin{tabular}{|c|c|c|c|c|}
\hline Level & $b\left(\mathrm{~kg} / \mathrm{m}^{3}\right)$ & $\mathrm{Sp}(\%)$ & $\mathrm{W} / \mathrm{b}(\%)$ & Pozzolan $(\%)$ \\
\hline 1 & 400 & 0 & 0.4 & 0 \\
\hline 2 & 450 & 0.7 & 0.45 & 10 \\
\hline 3 & - & - & - & 20 \\
\hline 4 & - & - & - & 25 \\
\hline
\end{tabular}

In this study, 8 mix designs were used based on the proposed Taguchi method. Each mix design consists of 12 samples, 6 samples for the storage in pond 1 (the pond containing drinking water) and the other 6 samples were used for the storage in pond 2 (the pond containing Oman Sea water). The temperature of the sample storage ponds was kept constant at $28 \pm 3{ }^{\circ} \mathrm{C}$. The tests performed on the samples are the BS EN 12390-8 permeability test and BS 1881-part122 half-hour water absorption test, both of which are among the most important tests recommended in the "National Concrete Durability Regulation in Oman Sea" for the evaluation of concrete samples. The experiments were performed on the samples at 28 days. The water permeability test of the relevant standard required more time for the test because of spending more time ( $72 \pm 2$ hours for each mix design in each pond) than the other permeability tests.

Taguchi proposed the $\mathrm{L}_{8}$ orthogonal arrays $(8 \mathrm{mix}$ designs) for this experiment, as shown in Tab. 2, which gives the details of the mix designs in Tab. 3 with respect to the proposed levels for each mix design.

Table $2 \mathrm{~L} 8$ standard arrays

\begin{tabular}{|c|c|c|c|c|}
\hline & \multicolumn{4}{|c|}{ Independent Variables } \\
\hline Test No. & $\mathrm{b}\left(\mathrm{kg} / \mathrm{m}^{3}\right)$ & $\mathrm{Sp}(\%)$ & $\mathrm{w} / \mathrm{b}(\%)$ & Pozzolan (\%) \\
\hline M1 & 1 & 1 & 1 & 1 \\
\hline M2 & 2 & 2 & 2 & 1 \\
\hline M3 & 2 & 1 & 1 & 2 \\
\hline M4 & 1 & 2 & 2 & 2 \\
\hline M5 & 1 & 2 & 1 & 3 \\
\hline M6 & 2 & 1 & 2 & 3 \\
\hline M7 & 2 & 2 & 1 & 4 \\
\hline M8 & 1 & 1 & 2 & 4 \\
\hline
\end{tabular}


Table 3 Details of Taguchi proposed mix designs

\begin{tabular}{|c|c|c|c|c|}
\hline \multirow{2}{*}{ Test No. } & \multicolumn{4}{|c|}{ Independent Variables } \\
\cline { 2 - 5 } & $\mathrm{b}\left(\mathrm{kg} / \mathrm{m}^{3}\right)$ & $\mathrm{Sp}(\%)$ & $\mathrm{w} / \mathrm{b}(\%)$ & Pozzolan $(\%)$ \\
\hline M1 & 400 & 0 & 0.4 & 0 \\
\hline M2 & 450 & 1 & 0.45 & 0 \\
\hline M3 & 450 & 0 & 0.4 & 10 \\
\hline M4 & 400 & 1 & 0.45 & 10 \\
\hline M5 & 400 & 1 & 0.4 & 20 \\
\hline M6 & 450 & 0 & 0.45 & 20 \\
\hline M7 & 450 & 1 & 0.4 & 25 \\
\hline M8 & 400 & 0 & 0.45 & 25 \\
\hline
\end{tabular}

\section{MATERIALS}

The cement used in the experiment is the cement type II and the pozzolan used is the Taftan natural pozzolan. The results of chemical analysis of cement and pozzolan used in the experiments are presented in Tab. 4.

Table 4 Physical and chemical properties of Portland cement and mineral admixture

\begin{tabular}{|c|c|c|}
\hline Physical properties & Portland cement & Taftan pozzolan \\
\hline Specific surface area $\left(\mathrm{g} / \mathrm{cm}^{2}\right)$ & $2850-3000$ & - \\
\hline Setting time & & - \\
\hline Primary $(\mathrm{min})$ & $90-110$ & - \\
\hline Secondary $(\mathrm{min})$ & $130-180$ & - \\
\hline Compressive strength & & - \\
\hline 3 -day $\left(\mathrm{kg} / \mathrm{m}^{2}\right)$ & $180-230$ & - \\
\hline 7 -day $\left(\mathrm{kg} / \mathrm{m}^{2}\right)$ & $290-330$ & \\
\hline 28 -day $\left(\mathrm{kg} / \mathrm{m}^{2}\right)$ & $410-450$ & $60-62$ \\
\hline Chemical analysis & & $6.5-7.1$ \\
\hline $\mathrm{SiO}_{2}$ & $21.5-22$ & $17.8-18.5$ \\
\hline $\mathrm{CaO}$ & $63.4-64.2$ & $4.6-5.5$ \\
\hline $\mathrm{Al}_{2} \mathrm{O}_{3}$ & $4.8-5.2$ & $<2.8$ \\
\hline $\mathrm{Fe}_{2} \mathrm{O}_{3}$ & $3.7-4.1$ & $<0.2$ \\
\hline $\mathrm{MgO}_{\mathrm{SO}}$ & $2.3-2.6$ & $<2.5$ \\
\hline $\mathrm{Cl}$ & $1.2-1.6$ & $<2$ \\
\hline $\mathrm{K}_{2} \mathrm{O}$ & $<0.04$ & - \\
\hline $\mathrm{Na}_{2} \mathrm{O}$ & 0.6 & - \\
\hline $\mathrm{C}_{3} \mathrm{~S}$ & 0.4 & - \\
\hline $\mathrm{C}_{2} \mathrm{~S}$ & 56 & - \\
\hline $\mathrm{C}_{3} \mathrm{~A}$ & 15 & $<2.5$ \\
\hline Loss of ignition & $7-7.5$ & \\
\hline & $0.5-0.8$ & \\
\hline
\end{tabular}

The sand and gravel consumed in this study were obtained from a factory in Zahedan which did not meet ASTM C33 standards [20], and the grading was modified, and the grading results after modifying the aggregates are presented in Tabs. 5 and 6 . The maximum gravel size, water absorption percentage, and gravel density are $16 \mathrm{~mm}, 1.1 \%$ and 2.75 , respectively. Also, the consumed sand has a density of 2.65 and water absorption of $2.1 \%$.

Table 5 Results of gravel grading

\begin{tabular}{|c|c|c|c|c|c|c|}
\hline Sieve size (mm) & 25.4 & 19 & 12.5 & 9.5 & $\# 4$ & $\# 8$ \\
\hline $\begin{array}{c}\text { Cumulative percentage } \\
\text { of grain passed through } \\
\text { sieve }\end{array}$ & 100 & 90.2 & 40 & 14 & 1 & 0.1 \\
\hline $\begin{array}{c}\text { Allowable range } \\
\text { ASTM-C33 (\%) }\end{array}$ & 100 & $90-100$ & $20-55$ & $0-15$ & $0-5$ & - \\
\hline
\end{tabular}

The grade of cement used (pozzolan $+c$ ) in this study is $400 \mathrm{~kg} / \mathrm{m}^{3}$ and $450 \mathrm{~kg} / \mathrm{m}^{3}$ (Tab. 3). Due to the necessity for keeping the slump of samples between 70 to $110 \mathrm{~mm}$ and the high grade of cement used, the concrete slump of mix designs kept constant with a small percentage of super-plasticizer without increasing the water. Tab. 7 presents the superplasticizer specifications and the sample mix design. It should be noted that the percentage of super-plasticizer consumption recommended by the manufacturer is $0.6-2.5 \%$ by weight of cement. The used super-plasticizer is based on melamine.

Table 6 Results of sand grading

\begin{tabular}{|c|c|c|c|}
\hline $\begin{array}{c}\text { Sieve } \\
\text { No. }\end{array}$ & $\begin{array}{c}\text { Allowable range } \\
\text { ASTM C 33 }\end{array}$ & $\begin{array}{c}\text { Passed percentage } \\
\text { (before modification) }\end{array}$ & $\begin{array}{c}\text { Passed percentage } \\
\text { (after modification) }\end{array}$ \\
\hline 200 & 0 & 1.2 & 0 \\
\hline 100 & $2-10$ & 4 & 7 \\
\hline 50 & $10-30$ & 7 & 24 \\
\hline 30 & $25-60$ & 20 & 40 \\
\hline 16 & $50-85$ & 35 & 69 \\
\hline 8 & $80-100$ & 69 & 89 \\
\hline 4 & $90-100$ & 84 & 95 \\
\hline $3 / 8$ & 100 & 100 & 100 \\
\hline
\end{tabular}

Table 7 Super-plasticizer specifications

\begin{tabular}{|c|c|}
\hline Physical properties & partially concentrated liquid \\
\hline Color & Light brown \\
\hline Density & $1.2 \mathrm{~kg} / \mathrm{m}^{3}$ \\
\hline $\mathrm{pH}$ & 6.9 \\
\hline Other specifications & Without chlorine ion and non-flammable \\
\hline
\end{tabular}

Tab. 8 compares the analysis of the main salts in the waters of the Oman Sea with the salts in the high seas of the world as a measure, considering that the waters of the Oman Sea were used in one of the ponds.

Table 8 Comparison between high seas and Oman Sea water decomposition

\begin{tabular}{|c|c|c|}
\hline Minerals & $\begin{array}{c}\text { Minerals existing in sea } \\
\text { water }(\mathrm{ppm})\end{array}$ & $\begin{array}{c}\text { Minerals existing in Oman Sea } \\
\text { water (ppm) }\end{array}$ \\
\hline Calcium & $50-480$ & 460 \\
\hline Magnesium & $260-1410$ & 1400 \\
\hline Sodium & $2190-12200$ & 12500 \\
\hline Potassium & $70-550$ & 420 \\
\hline Sulfate & $580-2810$ & 2900 \\
\hline Chlorine & $3960-20000$ & 21100 \\
\hline
\end{tabular}

\section{PREPARATION OF TEST SAMPLES}

In this study, ACI-211 [22] was used for the volumetric concrete mix design method. The samples were removed from the mold after $24 \mathrm{~h}$ and kept in lime water solution for 7 days. After 7 days, the samples were transferred to two drinking water and Oman Sea water ponds. The permeability test samples are $150 \mathrm{~mm}$ cubic samples as per BS EN 123908 , and 6 samples were prepared for each mix design. Also, the cylindrical samples were $7.5 \times 7.5$ as per BS 1881-part 122 for water absorption test.

\section{EXPERIMENTS}

Concrete permeability is usually obtained by calculating the pressurized water that enters a concrete sample. In the research method, according to BS EN 12390-8, the $15 \times 15$ $\times 15 \mathrm{~cm}$ cubic concrete samples are subjected to constant pressure of $5 \mathrm{~atm}$. After 3 days, the samples are divided into two halves and the amount of permeation is measured [19]. 
Figs. 1 and 2 show a view of the permeability test device, split sample, and area of water permeation.

The water absorption test is performed according to BS1881 where the $7.5 \times 7.5$ cylindrical samples are placed in the oven for 72 hours at $110^{\circ} \mathrm{C}$ and, after cooling, for 30 minutes inside the water. After drying the surface of the samples, the water absorption percentage of the samples is obtained during this time. In this paper, the water absorption test is performed according to BS1881-part 122.

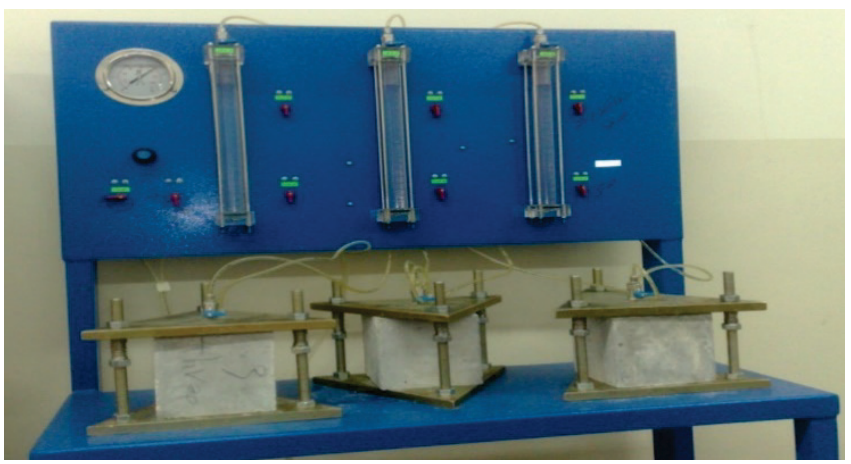

Figure 1 View of water permeability device in concrete

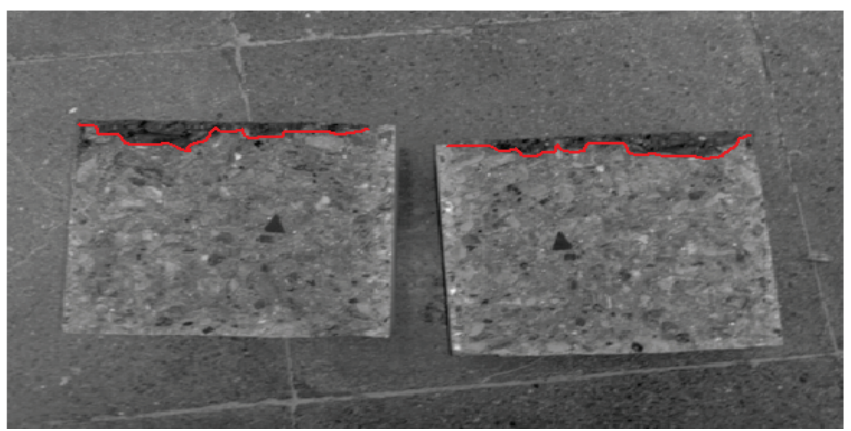

Figure 2 Example of water permeation in cubic sample

The results of the water permeability and absorption tests are presented in Tab. 9. Each value in this table is the average of the results from three concrete samples tested in drinking water and Oman Sea waters.

Table 9 Results of 28-day water permeability and absorption tests

\begin{tabular}{|c|c|c|c|c|}
\hline $\begin{array}{c}\text { Testing } \\
\text { Environment }\end{array}$ & \multicolumn{2}{|c|}{ Sea Water } & \multicolumn{2}{|c|}{ Drinking Water } \\
\hline Test & $\begin{array}{l}\text { Half-hour } \\
\text { water } \\
\text { absorption } \\
\end{array}$ & $\begin{array}{c}\text { Water } \\
\text { permeability } \\
(\mathrm{mm})\end{array}$ & $\begin{array}{l}\text { Half-hour } \\
\text { water } \\
\text { absorption }\end{array}$ & $\begin{array}{c}\text { Water } \\
\text { permeability } \\
(\mathrm{mm})\end{array}$ \\
\hline M1 & 2.71 & 17.2 & 2.55 & 14.6 \\
\hline M2 & 2.72 & 17.3 & 2.56 & 14.6 \\
\hline M3 & 2.48 & 15.5 & 2.3 & 12.8 \\
\hline M4 & 2.79 & 17 & 2.58 & 14.5 \\
\hline M5 & 2.38 & 14.4 & 2.18 & 11.6 \\
\hline M6 & 2.49 & 15 & 2.26 & 12.65 \\
\hline M7 & 2.1 & 13.7 & 1.9 & 11 \\
\hline M8 & 2.5 & 16 & 2.29 & 13.4 \\
\hline
\end{tabular}

According to Tab. 3 and the results of Tab. 9, it is observed that in all the samples that used pozzolan, the water absorption and permeability values decreased. One reason is that the addition of pozzolan to concrete reduces the large pores to small ones, thereby reducing the concrete permeability. On the other hand, the secondary cement properties of pozzolan cause the pozzolan to consume calcium hydroxide in the cement paste, thereby reducing the amount of lime which is an important factor in the damage caused by sulfate attacks. Pozzolan strengthens the concrete interfacial transition zone (ITZ) (aggregate and paste interface) by converting lime to C-S-H, thereby improving the concrete properties.

Based on the laboratory results (Tab. 9), although sample M7 has the best result among the proposed initial samples, it cannot be stated that the M7 mix design is the most optimal one. Therefore, by presenting the results of the $8 \mathrm{mix}$ designs by the Taguchi optimization method, the most optimal design was obtained (which may not be in the tests).

\subsection{Obtaining Optimal Mix Design by Taguchi Method}

In this study, the best (most effective) level of each factor was determined for each experiment. Using Minitab software and the plotted graphs and considering the "Smaller the better" for both experiments, the values of the $\mathrm{S} / \mathrm{N}$ ratios can be used to determine the most effective parameters in each experiment and the optimal mix designs. The graphs in Figs. 3-6 show the results of each experiment.

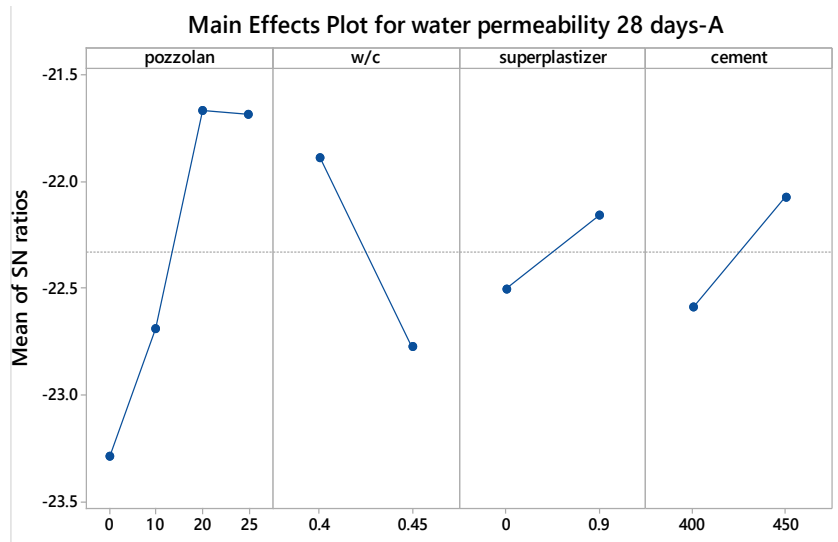

Figure $3 \mathrm{~S} / \mathrm{N}$ graph for water permeability test of samples in pond 1

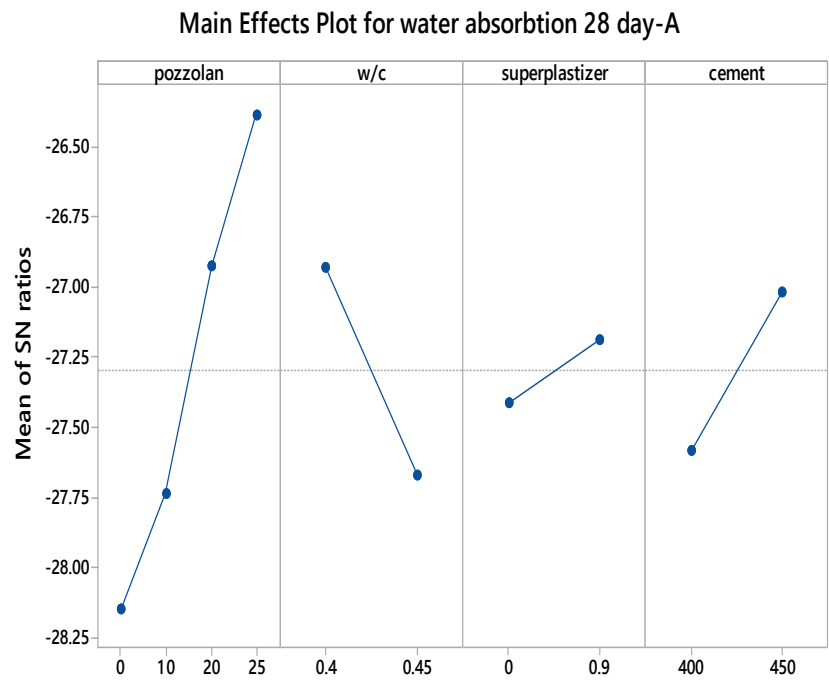

Figure $4 \mathrm{~S} / \mathrm{N}$ graph for water absorption test of samples in pond 1 


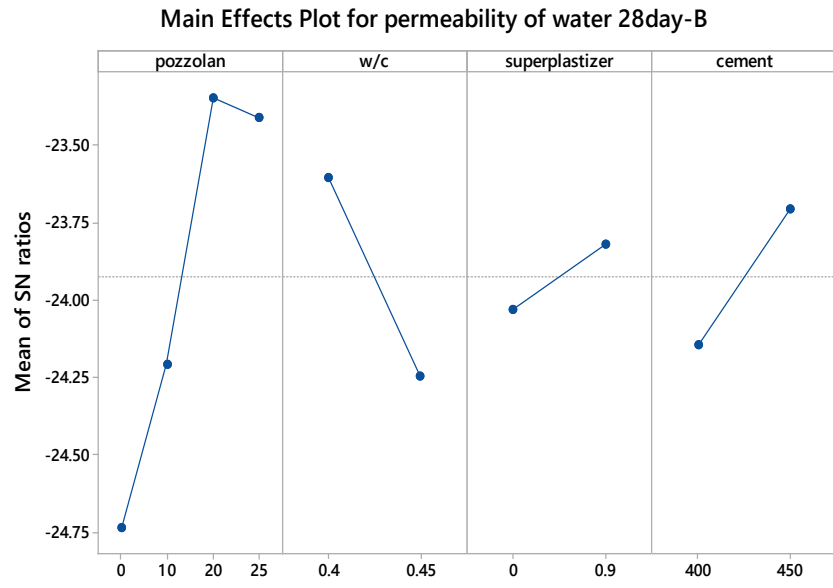

Figure $5 \mathrm{~S} / \mathrm{N}$ graph for water permeability test of samples in pond 2

Main Effects Plot for water absorbtion 28 day-B

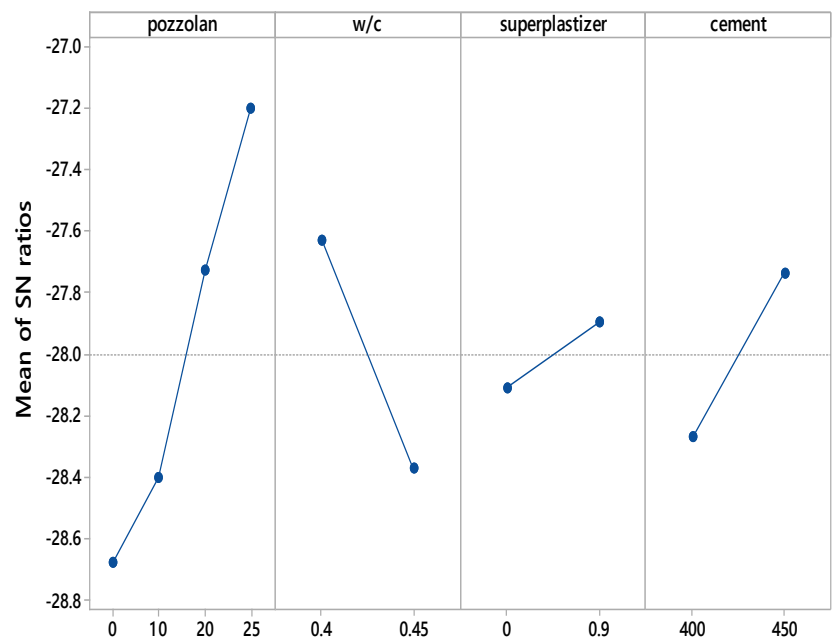

Figure $6 \mathrm{~S} / \mathrm{N}$ graph for water absorption test of samples in pond 2

Figs. 3-4 are related to pond 1 (drinking water) and Figs. 4-5 are related to pond 2 (sea water). In these figures, in each parameter, the level that has the highest $\mathrm{S} / \mathrm{N}$ value is specified as the best level of the parameter. The $\mathrm{S} / \mathrm{N}$ results for Figs. 3-5 are presented in Tab. 10.
According to the graphs of water permeability and absorption test results, the higher the amount of pozzolan consumed, the greater the effect on the results of the water absorption test, but the permeability test graphs show that an increase in used pozzolan up to $20 \%$ has a positive effect on our results, but with a $25 \%$ substitution, we can see the reduced effect of added pozzolan on the permeability of the samples.

In Tab. 10, the Delta value is the difference between the highest and the lowest parameter levels. The higher this value, the greater the rank parameter that indicates the greater effect of the parameter on the experiment. By observing the rank parameter for the water permeability and absorption tests, it can be stated that the amount of pozzolan consumed has the greatest effect on the results of the experiments.

Also, the next effective parameter is the water to cement ratio $(\mathrm{w} / \mathrm{b})$ and ultimately, the amount of super-plasticizer has the least effect on the results of the experiments. Table 11 was obtained using the analysis of variance (ANOVA) and considering the parameters of Table 1 as independent variables. The higher the F-Value in this table, the greater the effect of the parameter on the test result. According to Figs. 3 to 6 , the optimal mix design for each experiment and each environment can be obtained. Tab. 12 presents the optimal mix designs.

Tab. 12 presents the predicted values from the optimal mix design. For the validation of these values, 2 mix designs each containing 6 samples were prepared (In the laboratory conditions, the initial samples were cured and constructed, and by comparing the estimated results with the results of the mix designs, this method was validated for predicting the optimal mix design).

Tab. 13 compares the results of the M7 mix design (the best behavior in the proposed Taguchi initial samples) with the optimal Taguchi mix design. The results show that although the half-hour water absorption results did not change in the optimal Taguchi design compared to M7, the concrete permeability improved in the concrete made from the Taguchi optimal design.

Table $10 \mathrm{~S} / \mathrm{N}$ values for samples in ponds 1 and 2

\begin{tabular}{|c|c|c|c|c|c|c|c|c|}
\hline \multirow{9}{*}{ Pond 1} & \multirow{5}{*}{ Permeability test } & Parameter & Level 1 & Level 2 & Level 3 & Level 4 & Delta & Rank \\
\hline & & pozzolan & -23.29 & -22.69 & -21.67 & -21.68 & 1.62 & 1 \\
\hline & & $\mathrm{w} / \mathrm{b}$ & -21.89 & -22.77 & & & 0.89 & 2 \\
\hline & & $\mathrm{sp}$ & -22.50 & -22.16 & & & 0.35 & 4 \\
\hline & & cement & -22.59 & -22.08 & & & 0.51 & 3 \\
\hline & \multirow{4}{*}{ Absorption test } & pozzolan & -28.15 & -27.73 & -26.93 & -26.39 & 1.76 & 1 \\
\hline & & $\mathrm{w} / \mathrm{b}$ & -26.93 & -27.67 & & & 0.74 & 2 \\
\hline & & $\mathrm{sp}$ & -27.41 & -27.19 & & & 0.23 & 3 \\
\hline & & cement & -27.58 & -27.01 & & & 0.57 & 4 \\
\hline \multirow{8}{*}{ Pond 2} & \multirow{4}{*}{ Permeability test } & pozzolan & -24.74 & -24.21 & -23.34 & -23.41 & 1.39 & 1 \\
\hline & & $\mathrm{w} / \mathrm{b}$ & -23.60 & -24.24 & & & 0.64 & 2 \\
\hline & & $\mathrm{sp}$ & -24.03 & -23.82 & & & 0.21 & 4 \\
\hline & & cement & -24.14 & -23.71 & & & & 3 \\
\hline & & pozzolan & -28.68 & -28.40 & -27.73 & -27.20 & 1.47 & 1 \\
\hline & & $\mathrm{w} / \mathrm{b}$ & -27.63 & -28.37 & & & 0.74 & 2 \\
\hline & & $\mathrm{sp}$ & -28.11 & -27.89 & & & 0.21 & 4 \\
\hline & & cement & -28.27 & -27.74 & & & & 3 \\
\hline
\end{tabular}


Table 11 Analysis of variance (ANOVA) for results of experiments in both ponds

\begin{tabular}{|c|c|c|c|c|c|c|c|}
\hline & & & $\mathrm{DF}$ & Adj SS & Adj MS & F-Value & P-Value \\
\hline \multirow{12}{*}{ Pond 1} & \multirow{6}{*}{ Permeability test } & pozzolan & 1 & 7.61 & 7.61 & 22.53 & 0.018 \\
\hline & & $\mathrm{w} / \mathrm{bs}$ & 1 & 3.31 & 3.31 & 9.81 & 0.052 \\
\hline & & $\mathrm{sp}$ & 1 & 0.38 & 0.38 & 1.13 & 0.365 \\
\hline & & cement & 1 & 1.16 & 1.16 & 3.44 & 0.162 \\
\hline & & Error & 3 & 1.01 & 0.34 & & \\
\hline & & Total & 7 & 13.48 & & & \\
\hline & \multirow{6}{*}{ Absorption test } & pozzolan & 1 & 25.6 & 25.6 & 180.71 & 0.001 \\
\hline & & $\mathrm{w} / \mathrm{b}$ & 1 & 7.22 & 7.22 & 50.96 & 0.006 \\
\hline & & $\mathrm{sp}$ & 1 & 0.405 & 0.405 & 2.86 & 0.189 \\
\hline & & cement & 1 & 4.205 & 4.205 & 29.68 & 0.012 \\
\hline & & Error & 3 & 0.42 & 0.141 & & \\
\hline & & Total & 7 & 37.85 & & & \\
\hline \multirow{12}{*}{ Pond 2} & \multirow{6}{*}{ Permeability test } & pozzolan & 1 & 7.66 & 7.66 & 19.5 & 0.022 \\
\hline & & $\mathrm{w} / \mathrm{b}$ & 1 & 2.53 & 2.53 & 6.4 & 0.085 \\
\hline & & $\mathrm{sp}$ & 1 & 0.21 & 0.21 & 0.54 & 0.517 \\
\hline & & cement & 1 & 1.20 & 1.20 & 3.06 & 0.179 \\
\hline & & Error & 3 & 1.18 & 0.39 & & \\
\hline & & Total & 7 & 12.78 & & & \\
\hline & \multirow{6}{*}{ Absorption test } & pozzolan & 1 & 20.88 & 20.88 & 126.61 & 0.002 \\
\hline & & $\mathrm{w} / \mathrm{b}$ & 1 & 8.61 & 8.61 & 52.22 & 0.005 \\
\hline & & $\mathrm{sp}$ & 1 & 0.45 & 0.45 & 2.74 & 0.197 \\
\hline & & cement & 1 & 4.35 & 4.35 & 26.38 & 0.014 \\
\hline & & Error & 3 & 0.49 & 0.16 & & \\
\hline & & Total & 7 & 34.79 & & & \\
\hline
\end{tabular}

Table 12 Optimal mix design values

\begin{tabular}{|c|c|c|c|c|c|c|c|}
\hline & & & pozzolan & $\mathrm{w} / \mathrm{b}$ & $\mathrm{sp}$ & cement & Value obtained from test for optimal mix design \\
\hline \multirow{4}{*}{ Drinking water } & \multirow{2}{*}{ 28-day permeability } & value & 20 & 0.4 & 0.7 & 450 & 10.88 \\
\hline & & level & 3 & 1 & 2 & 2 & \\
\hline & \multirow{2}{*}{ 28-day absorption } & value & 25 & 0.4 & 0.7 & 450 & 1.9 \\
\hline & & level & 4 & 1 & 2 & 2 & \\
\hline \multirow{4}{*}{ Sea water } & \multirow{2}{*}{ 28-day permeability } & value & 20 & 0.4 & 0.7 & 450 & 13.56 \\
\hline & & level & 3 & 1 & 2 & 2 & \\
\hline & \multirow{2}{*}{ 28-day absorption } & value & 25 & 0.4 & 0.7 & 450 & 2.1 \\
\hline & & level & 4 & 1 & 2 & 2 & \\
\hline
\end{tabular}

Table 13 Compares of results of the M7 mix design with the optimal Taguchi mix design

\begin{tabular}{|c|c|c|c|c|}
\cline { 2 - 5 } \multicolumn{1}{c|}{} & \multicolumn{2}{c|}{ Sea water } & \multicolumn{2}{c|}{ Drinking water } \\
\hline Parameter & $\begin{array}{c}\text { Half-hour } \\
\text { water } \\
\text { Test }\end{array}$ & $\begin{array}{c}\text { Water } \\
\text { permeability } \\
(\%)\end{array}$ & $\begin{array}{c}\text { Half-hour } \\
\text { water } \\
\text { absorption } \\
(\%)\end{array}$ & $\begin{array}{c}\text { Water } \\
\text { permeability } \\
(\mathrm{mm})\end{array}$ \\
\hline $\begin{array}{c}\text { M7 } \\
\text { M }\end{array}$ & 2.1 & 13.7 & 1.9 & 11 \\
\hline \begin{tabular}{c} 
(optimization) \\
\hline
\end{tabular} & 2.1 & 13.56 & 1.9 & 10.88 \\
\hline
\end{tabular}

Tab. 14 presents the limitations of the National Concrete Durability Regulation for water permeability and absorption in the Oman Sea and the Persian Gulf [23].

Table 14 Limitations of National Concrete Durability Regulation for water permeability and absorption in Oman Sea

\begin{tabular}{|c|c|c|c|}
\hline \multirow{2}{*}{ Test } & \multicolumn{3}{|c|}{ Allowable range } \\
\cline { 2 - 4 } & $\begin{array}{c}\text { Moderate } \\
\text { conditions }\end{array}$ & $\begin{array}{c}\text { Severe } \\
\text { conditions }\end{array}$ & $\begin{array}{c}\text { Extreme } \\
\text { conditions }\end{array}$ \\
\hline $\begin{array}{c}\text { 1. Half-hour water } \\
\text { absorption (28 days) }\end{array}$ & Max 4\% & Max 3\% & Max 2\% \\
$\begin{array}{c}\text { 2. Water permeability } \\
\text { (28 days) }\end{array}$ & Max 50 mm & Max 30 mm & Max 10 mm \\
\hline
\end{tabular}

According to the results of the experiments from the Taguchi optimal mix design and the limitations of the National Concrete Durability Regulation in the Oman Sea, it can be concluded that by observing the limitations of this regulation and the positive effects of Taftan pozzolan on improving the water permeability and absorption properties, the pozzolans can be used as an mineral admixture to improve concrete properties under moderate to severe attack conditions. However, for the use in extreme conditions, due to the strict regulation limitations (Tab. 14), it is not sufficient to simply add this pozzolan to the concrete. Using this pozzolan increased the water absorption value of concrete to $2.1 \%$ and the permeability of concrete in the optimal mix design to $14.5 \mathrm{~mm}$, which are close to the maximum allowable values. It is possible to meet the criteria considered in the regulation by adding a higher percentage of superplasticizer or modifying the aggregates and reducing the water-to-cement ratio.

\section{CONCLUSION}

In this paper, the effect of using Taftan pozzolan on the water permeability and absorption of concrete structures in the Oman Sea and drinking water was investigated. The Taguchi optimization method was used to reduce the time and cost of sample construction. The four parameters of water to cement ratio, different percentages of natural pozzolan, super-plasticizer, and grade of cementitious materials with different ratios were considered as problem variables. The Taguchi method proposed $8 \mathrm{mix}$ designs, and 
192 samples were prepared to validate the results and tested in the both Oman Sea and drinking waters. By comparing the results with the National Concrete Durability Regulation in the Persian Gulf and Oman Sea, it was found that the use of Taftan pozzolan was effective in reducing the water permeability $(20 \%)$ and absorption in the moderate to severe conditions $(25 \%)$. In the extreme conditions, the results are close to the critical limits of the regulation, but they failed to meet the regulation criteria. Taguchi method can determine the ratio of the use of pozzolans in the designed concrete mixing ratio with an accuracy of about $2 \%$ compared to the laboratory results.

\section{REFERENCES}

[1] Uzal, B., \& Turanli, L. U. T. F. U. L. L. A. H. (2003). Studies on blended cements containing a high volume of natural pozzolans. Cement and Concrete Research,33(11), 17771781. https://doi.org/10.1016/S0008-8846(03)00173-X

[2] Najimi, M., Sobhani, J., Ahmadi, B., \& Shekarchi, M. (2012). An experimental study on durability properties of concrete containing zeolite as a highly reactive natural pozzolan. Construction and Building Materials, 35, 1023-1033. https://doi.org/10.1016/j.conbuildmat.2012.04.038

[3] Ezziane, K., Bougara, A., Kadri, A., Khelafi, H., \& Kadri, E. (2007). Compressive strength of mortar containing natural pozzolan under various curing temperature. Cement and Concrete Composites, 29(8), 587-593. https://doi.org/10.1016/j.cemconcomp.2007.03.002

[4] Nguyen, V. H., Leklou, N., Aubert, J. E., \& Mounanga, P. (2013). The effect of natural pozzolan on delayed ettringite formation of the heat-cured mortars. Construction and Building Materials, 48, 479-484. https://doi.org/10.1016/j.conbuildmat.2013.07.016

[5] Ghrici, M., Kenai, S., \& Said-Mansour, M. (2007). Mechanical properties and durability of mortar and concrete containing natural pozzolana and limestone blended cements. Cement and Concrete Composites, 29(7), 542-549. https://doi.org/10.1016/j.cemconcomp.2007.04.009

[6] Bondar, D., Lynsdale, C. J., Milestone, N. B., Hassani, N., \& Ramezanianpour, A. A. (2011). Effect of adding mineral additives to alkali-activated natural pozzolan paste. Construction and Building Materials, 25(6), 2906-2910. https://doi.org/10.1016/j.conbuildmat.2010.12.031

[7] Kaid, N., Cyr, M., Julien, S., \& Khelafi, H. (2009). Durability of concrete containing a natural pozzolan as defined by a performance-based approach. Construction and Building Materials, 23(12), 3457-3467. https://doi.org/10.1016/j.conbuildmat.2009.08.002

[8] EN, B. S. (2000). 12390-8 Depth of penetration of water under pressure. British Standards Institution.

[9] Standard, B. \& ISO, B. (1999). Plastics-Determination of water absorption. PN-EN ISO, 62.

[10] Merida, A. \& Kharchi, F. (2015). Pozzolan concrete durability on sulphate attack. Procedia Engineering, 114, 832-837. https://doi.org/10.1016/j.proeng.2015.08.035

[11] Omrane, M., Kenai, S., Kadri, E. H., \& Aït-Mokhtar, A. (2017). Performance and durability of self compacting concrete using recycled concrete aggregates and natural pozzolan. Journal of Cleaner Production, 165, 415-430. https://doi.org/10.1016/j.jclepro.2017.07.139

[12] Firdous, R., Stephan, D., \& Djobo, J. N. Y. (2018). Natural pozzolan based geopolymers: a review on mechanical, microstructural and durability characteristics. Construction and Building Materials, 190, 1251-1263. https://doi.org/10.1016/j.conbuildmat.2018.09.191

[13] Najimi, M. \& Ghafoori, N. (2019). Engineering properties of natural pozzolan/slag based alkali-activated concrete. Construction and Building Materials, 208, 46-62. https://doi.org/10.1016/j.conbuildmat.2019.02.107

[14] Ranjit, K. (1990). Roy, 1990. A primer on the Taguchi method. Soc. Manufac. Eng.

[15] Ibrahim, M. R., Ismail, N., Leman, Z., \& Majid, D. L. A. H. A. (2012). Experimental investigation of HSS face milling to AL6061 using Taguchi method. Procedia Engineering, 50, 933-941.

[16] Ozbay, E., Oztas, A., Baykasoglu, A., \& Ozbebek, H. (2009). Investigating mix proportions of high strength self compacting concrete by using Taguchi method. Construction and building materials, 23(2), 694-702. https://doi.org/10.1016/j.conbuildmat.2008.02.014

[17] Türkmen, İ., Gül, R., \& Çelik, C. (2008). A Taguchi approach for investigation of some physical properties of concrete produced from mineral admixtures. Building and environment, 43(6), 1127-1137. https://doi.org/10.1016/j.buildenv.2007.02.005

[18] Lyu, S. R., Te Wu, W., Hou, C. C., \& Hsieh, W. H. (2010). Study of cryopreservation of articular chondrocytes using the Taguchi method. Cryobiology, 60(2), 165-176. https://doi.org/10.1016/j.cryobiol.2009.10.008

[19] Fowlkes, W. Y. \& Creveling, C. M. (1995). Engineering methods for robust product design: using Taguchi methods in technology and product development. Addison-Wesley.

[20] Phadke, M. S. (1989). Quality engineering using robust design: Produkt-u. Prozeßoptimierung mit d. Methoden $d$. statistischen Versuchsplanung nach G. Taguchi. Gfmt, Ges. für Management und Technologie. https://doi.org/10.1007/978-1-4684-1472-1_3

[21] (2002). American Society for Testing and Materials, ASTM C33, Standard Specification for Concrete Aggregates.

[22] (2001). American Concrete Institute, ACI 211, Guide for Submittal of Concrete Proportions.

[23] Safehian, M. \& Ramezanianpour, A. A. (2013). Assessment of service life models for determination of chloride penetration into silica fume concrete in the severe marine environmental condition. Construction and Building Materials, 48, 287-294. https://doi.org/10.1016/j.conbuildmat.2013.07.006

\section{Authors' contacts:}

\section{Amir Behshad}

(Corresponding Author)

Faculty of Industry and Mining, Yasouj University,

12345 Yasouj, Iran

amir.behshad@hotmail.com

\section{Mostafa Askarian Zardak}

Department of Structural Engineering,

Zahedan University, Iran

\section{Yaser Mohammadi}

Ferdowsi University of Mashhad,

Mashhad, Iran 